\title{
Development of Macromedia Captivate-Based Instructional Media of Social Studies on Scarcity and Human Needs Material of Grade VII at Islamic Junior High School of Assyafiiyah Gondang Tulungagung
}

\author{
$1^{\text {st }}$ Dwi Astuti Wahyu Nurhayati* \\ State Islamic Institute of Tulungagung \\ Tulungagung, Indonesia \\ dwiastuti507@gmail.com \\ dwiastuti@iain-tulungagung.ac.id
}

\author{
$2^{\text {nd }}$ Maryono \\ State Islamic Institute of Tulungagung \\ Tulungagung, Indonesia \\ mariostain@yahoo.com

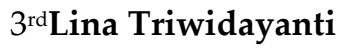 \\ State Islamic Institute of Tulungagung, \\ Tulungagung, Indonesia \\ Linatriwidayanti02@gmail.com
}

\begin{abstract}
This research is driven by the phenomenon of numerous students who often fail to notice the previous material, and due to inadequate learning media of Social Studies. Based on the results of observation during the learning process, students often forgot the previous materials, lacked focus on the materials, and had inadequate learning resources. This research aims to analyze the level of validity, practicality, and effectiveness of a macromedia captivate-based instructional media of social studies on scarcity and human needs material of grade VII at Islamic Junior High School of Assyafiiyah, Gondang, Tulungagung. This research was a development research that is used to produce a product. Procedures of this research and development consisted of research and data collection, planning, product draft development, product validation, product revision,
\end{abstract}

\section{INTRODUCTION}

Education is the entire phase of developing human abilities and behaviors. It is used in all aspects of life. This view suggests that education is crucial for humans in their lives, either for the environment or nation. As citizens who have responsibility, we should have the soul to realize the ideals of Indonesian people stated in the 1945 Constitution, that is, to educate the life of the nation. To clarify, Article 31, Paragraph 1, of the 1945 Constitution states, "every citizen has the right to education.

In accordance with the government regulations, education has a function and purpose to develop Indonesian people. This is stated in Law No. 20 of 2003 concerning the National Education System. According to the Law, Education functions to develop capabilities, as well as to shape characters $\odot 328$ Thational and field test. The result of the validation by media experts indicated that the instructional media met the valid criteria with the average percentage of $95.75 \%$. In addition, the validation of materials showed that the media met the valid criteria with the percentage of $93.65 \%$. The practicality test result showed that the media met 4 practicality criteria, which generally indicated that the media was practical. The validators stated that the media can be used with a minor revision. This result was evident in the score comparison obtained by both groups. The experimental group score was higher than that of the control group, that is, 84.13>71.93. Therefore, the macromedia captivate-based instructional media was declared effective.

Keywords-Development, Learning Media, Macromedia Captivate

civilization to educate the nation's life. Education aims at developing the potentials of students; that is, to be faithful and devoted to the Almighty God, have noble character, be skillful, competent, creative, independent, democratic, and respon sible citizens [1].

Based on problems lying in the rapid growth of science and technology as well as the low quality of education, interactive educational technology is worth developing. Educational technology is defined as the use of modern tools which are actually produced not for educational purposes, yet they can be used in education such as radio, $\mathrm{TV}$, video, computers, etc. [2]. Of the diverse types of educational technology, macromedia captivate is viewed effective in the learning process as it can engage many types of media. Through macromedia captivate, creating a simulation is straightforward. It is also possible to add and 
modify texts, insert audio (voice-overs, background, and sound effects), text animation, and pictures in creating a movie through macromedia captivate.

It is expected that by developing macromedia captivate media, learning objectives of Social Studies will be achieved. With this media, students are encouraged to be more active, and they are provided with a lot of questions to make them better comprehend the materials. The learning process will be more practical, varied, creative, and attractive; therefore, students are active in learning Social Studies both independently and in groups. This process will ultimately improve learning outcomes.

Some studies on the development of Macromedia Captivate are conducted by experts. [3] conducted research in developing the learning media of social studies based on macromedia captivate in Nurul Jadid Junior High School Paiton Probolinggo and she proved that learning media is appropriate to be used as one of the means in social studies learning activities and can improve the motivation so the result of study that achieved by students was increased. The result of assessment showed that material expert, media expert, practitioner/field teacher, the respons of students get the high percentage with valid qualification and there were no revision. Furthemore, Triharyati and [4] conducted study in using Macromedia Captivate with Group Investigation Teaching Learning Method. The study focused on knowing the result of learning using Macromedia Captivate combined with Group Investigation method on some subjects of learning such as: construction material picture frames, doors and windows. This study also gained students' responses on using Macromedia Captivate with Group Investigation Method. The result of the showed that there are differences between experimental class that was taught using macromedia captivate with group investigation method and control class that was taught using macromedia captivate with conventional method. The average of score of experimental class higher than control class. Using macromedia captivate with group investigation was considered cooperative. It also gained students' responses that they were satisfied and had interest in learning using Macromedia Captivated with Group Investigation. Then, [5] also conducted study on the use of Macromedia Captivate with
Make a Match learning style towards students' achievement in basic competence of understanding types of learning foundation. One aim of this study was to understand students' responses after implementing learning process using Macromedia Captivate-based media. The result showed that students' responses to Macromedia Captivate-based media for $86 \%$ of the proceeds qualify as strongly agree. It was also gained that it is feasible about $98 \%$ with a very decent qualification for use in teaching and learning activities. Next, [6] focused on the study on development of e-learning in Physics coursebased Captivate. The study aimed to describe the developing process of e-learning courses-based Adobe Captivate. The result of the study introduced that delivering courses through Adobe Captivate are well organized since the virtual, sounds, and delivered format, and the interactivity of Adobe Captivate-based course can be used as course especially in the developing exercise items as evaluation tool to assess students' comprehension. In addition, several studies regarding macromedia-captivate based media also have been done by [7]; [8]; [9]; and [10], but all of the studies little has been written regarding the development of macromedia captivate-based media concerning scarcity and human needs material on Social Studies subject of grade VII. Therefore, this study focuses on developing the media to figure out its level of validity, practicality, and effectiveness.

\section{METHOD}

This study employed a research and development research. A research and development is used to produce certain products and test the effectiveness of the products [11]. To produce a particular product, a need analysis and effectiveness test of the product is necessary to ensure that the product is decent and applicable. In this case, a research and development needs to be done in stages.

The development stages refers to the development model of [12] consisting of (1) research and information collecting; (2) planning; (3) develop preliminary form of product; (4) preliminary field testing; (5) main product revision; (6) main field testing; (7) operational product revision; (8) operational field testing; (9) final product revision; and (10) dissemination and implementation. 
Due to some considerations, the researchers modified the procedures of [12]. The procedures of this study only included research and information collecting, planning, develop preliminary form of product, expert validation, product revision, and product try-out [13].

The data were collected by using, interview, validation sheet, questionnaire, observation, and test. Interview was performed to find the problems; validation sheets were administered to the media and material experts to obtain the validity of the media; a questionnaire was given to the students to obtain the practicality of the media; whereas observation and test were performed to investigate the effectiveness of the media.

\section{RESULTS AND DISCUSSION}

Tests of the macromedia captivate-based instructional media were carried out in two stages, namely expert test and user test. In the expert test, the media was tested by program developers regarding the technical quality and functionality of the navigation buttons. In addition to program developers, the media was also tested by material experts and media experts. In the user test, the product was tested by teachers and students who will use macromedia captivate media.

\section{Expert Test}

a. Program Developers

The program test was performed by trying the functions of the navigation buttons, voice button, and other buttons repeatedly. The testing steps were carried out by running data input and seeing the output produced. This process was to check the product's conformity, errors, operation, and the suitability of data input and output.

b. Media Expert Validation

The validation was carried out by handing out the product to be checked and administering a validation sheet to the media experts. The media experts included a lecturer namely Nur Isroatul Khusna, M.Pd., and a Social Studies teacher namely Mustakim, S.Pd. The validation sheet consisted on 30 statements divided into 3 aspects namely A) Layout, B) Program, and C) Learning.

Table 1. Media Expert Validator

\begin{tabular}{clcc}
\hline No & Indicator & Validator & \\
\cline { 3 - 4 } & & $\mathbf{1}$ & $\mathbf{2}$ \\
\hline A & Layout Aspect & 4 & 4 \\
\hline 1 & Slide design in the media is fascinating. & 4 & 4 \\
\hline 2 & Main menu design in the media is fascinating. & 4 & 4 \\
\hline 3 & Menu placement in the media is suitable. & 3 & 4 \\
\hline 4 & Color selection in texts, pictures, and background is appropriate & 3 & 4 \\
\hline 5 & Color composition and combination are proper. & 4 & 4 \\
\hline 6 & Background selection is appropriate. & 4 & 4 \\
\hline 7 & Font size and type in the media are appropriate. & 4 & 4 \\
\hline 8 & Texts/sentences are readable. & 4 & 4 \\
\hline 9 & Button selection and placement are appropriate. & 4 & 4 \\
\hline 10 & Button size is acceptable. & & \\
\hline B & Program Aspect & 4 & 4 \\
\hline 1 & The media is easy to use. & 4 & 4 \\
\hline 2 & The media is user-friendly. & 4 & 4 \\
\hline 3 & Buttons in the media are consistent and suitable. & 4 & 4 \\
\hline 4 & All menus are well connected. & 4 & 4 \\
\hline 5 & All programs in the media run well. & 4 & 3 \\
\hline 6 & Slide composition is right. & 3 & 3 \\
\hline 7 & A guideline of using the media is clear. & 3 & 4 \\
\hline 8 & Menus are easy to choose. & 3 & 4 \\
\hline 9 & There is no error in the program. & 4 & 4 \\
\hline 10 & Cost and energy spent for the media are efficient. & & \\
\hline C & Learning Aspect & & \\
\hline & & & 4 \\
\hline
\end{tabular}




\begin{tabular}{clcc}
\hline 1 & $\begin{array}{l}\text { Media conformity among Core Competence, Basic Competence, and } \\
\text { learning objectives. }\end{array}$ & 4 & 4 \\
\hline 2 & Media suitability as the learning source. & 4 & 4 \\
\hline 3 & Learning plot in the media is clear. & 3 & 3 \\
\hline 4 & Social Studies materials are easy to understand. & 4 & 4 \\
\hline 5 & Media capability in developing the students' motivation. & 4 & 4 \\
\hline 6 & Media capability in attracting the students' attention in learning. & 4 & 4 \\
\hline 7 & Media capability to assist and remember information. & 4 & 4 \\
\hline 8 & Media capability to measure learning outcomes. & 4 & 4 \\
\hline 9 & Exercise tests are able to measure the students' skills. & 4 & 4 \\
\hline 10 & Ease of media in the learning activities. & 4 & 4 \\
\hline
\end{tabular}

Referring to table 1 , it is briefly exemplified the score of each validator for each aspect of test. Table 2 depicts the summary of the expert test.

Table 2: Summary Of Media Expert Validation

\begin{tabular}{|c|c|c|c|c|c|c|c|}
\hline \multirow[t]{2}{*}{ No } & \multirow[t]{2}{*}{ Validator } & \multicolumn{3}{|c|}{ Aspect } & \multirow{2}{*}{$\begin{array}{l}\text { Average } \\
\text { Score }\end{array}$} & \multirow{2}{*}{$\begin{array}{l}\text { Validity } \\
\text { Percentage }\end{array}$} & \multirow[t]{2}{*}{ Category } \\
\hline & & $\mathbf{A}$ & B & $\mathrm{C}$ & & & \\
\hline 1 & Validator 1 & 38 & 37 & 39 & 38 & $95 \%$ & Valid \\
\hline 2 & Validator 2 & 39 & 37 & 39 & 38.3 & $96.50 \%$ & Valid \\
\hline \multicolumn{2}{|c|}{ Total of Average Score } & \multicolumn{6}{|c|}{76.3} \\
\hline \multicolumn{2}{|c|}{ Validity Percentage } & \multicolumn{6}{|c|}{$95.75 \%$} \\
\hline \multicolumn{2}{|c|}{ Media Validation Category } & \multicolumn{6}{|c|}{ Valid } \\
\hline
\end{tabular}

c. Material Expert Validation

The validation was carried out by handing out the materials to be checked and adminis tering a validation sheet to material experts. The material experts included a lecturer namely
Choiru Ummatin, M.Pd., and a Social Studies teacher namely Mustakim, S.Pd. The validation sheet consisted on 30 statements divided into 3 aspects namely; a) Learning, b) Materials, and c) Interaction.

Table 3. Material Expert Validation

\begin{tabular}{clrc}
\hline No & Indicator & \multicolumn{2}{c}{ Validator } \\
\cline { 3 - 4 } & & $\mathbf{1}$ & $\mathbf{2}$ \\
\hline A & Learning Aspect & 4 & 4 \\
\hline 1 & Systematic presentation of the materials & 4 & 4 \\
\hline 2 & Clarity of learning guidelines & 3 & 4 \\
\hline 3 & Correctness of material explanation & 3 & 4 \\
\hline 4 & Correctness of key answers & 3 & 4 \\
\hline 5 & Clarity of materials & 4 & 3 \\
\hline 6 & Error-free in Social Studies concepts & 4 & 4 \\
\hline 7 & Selection of learning strategy (independent learning) & 4 & 3 \\
\hline 8 & Examples are appropriate with the materials & 4 & 4 \\
\hline 9 & Learning activities motivate students & 4 & 4 \\
\hline 10 & Examples provided conform to the indicators and learning Objectives & 4 & 4 \\
\hline B & Material Aspect & 4 & 4 \\
\hline 1 & The materials are comprehensive & 4 & 4 \\
\hline 2 & Correctness of the materials & 4 & 4 \\
\hline 3 & Clarity of texts or sentences & 4 & 4 \\
\hline 4 & Clarity of writing & 4 & 4 \\
\hline 5 & Suitability of examples with the materials & 4 & 4 \\
\hline 6 & Suitability of exercises with the materials & 4 & 4 \\
\hline 7 & Suitability of the materials with indicators & 4 & 4 \\
\hline
\end{tabular}




\begin{tabular}{clll}
\hline 8 & Consistency of presentation & 3 & 3 \\
\hline 9 & Appropriateness of language in explaining the materials & 3 & 3 \\
\hline 10 & Error-free in writing questions & 3 & 3 \\
\hline C & Interaction Aspect & 4 & 4 \\
\hline 1 & Clarity of learning objectives & 4 & 4 \\
\hline 2 & Clarity of learning plot & 4 & 3 \\
\hline 3 & Ease of understanding the materials & 4 & 4 \\
\hline 4 & Improving interest of learning & 4 & 4 \\
\hline 5 & Clarity of examples & 4 & 4 \\
\hline 6 & Diverse types of questions & 4 & 4 \\
\hline 7 & Varied level of difficulties of questions & 3 & 4 \\
\hline 8 & Enhancing the students' independence in learning & 4 & 3 \\
\hline 9 & Effectiveness of feedback questions & 4 & 4 \\
\hline 10 & Feedback is done immediately & 4 & 4 \\
\hline
\end{tabular}

As shown in table 3, the score of each validator is briefly presented. The summary of

the material expert validation is presented in table 4 .

Table 4. Summary of Material Expert Validation

\begin{tabular}{|c|c|c|c|c|c|c|c|}
\hline \multirow[t]{2}{*}{ No } & \multirow[t]{2}{*}{ Validator } & \multicolumn{3}{|c|}{ Aspect } & \multirow{2}{*}{$\begin{array}{l}\text { Average } \\
\text { Score }\end{array}$} & \multirow{2}{*}{$\begin{array}{l}\text { Validity } \\
\text { Percentage }\end{array}$} & \multirow[t]{2}{*}{ Category } \\
\hline & & $\mathrm{A}$ & B & $C$ & & & \\
\hline 1 & Validator 1 & 37 & 37 & 39 & 37.6 & $94 \%$ & Valid \\
\hline 2 & Validator 2 & 38 & 36 & 38 & 37.3 & $93.30 \%$ & Valid \\
\hline \multicolumn{2}{|c|}{ Total of Average Score } & \multicolumn{3}{|c|}{74.9} & & & \\
\hline \multicolumn{2}{|c|}{ Validity Percentage } & \multicolumn{3}{|c|}{$93.65 \%$} & & & \\
\hline \multicolumn{2}{|c|}{ Media Validation Category } & \multicolumn{3}{|c|}{ Valid } & & & \\
\hline
\end{tabular}

2. Validity Test of Posttest Questions

Table 5: Validity Result Of Posttest Questions

\begin{tabular}{|c|c|c|c|c|c|}
\hline \multirow[t]{2}{*}{ No } & \multirow[t]{2}{*}{ Criteria } & \multirow{2}{*}{$\begin{array}{l}\text { Question } \\
\text { Number }\end{array}$} & \multicolumn{2}{|c|}{ Validator } & \multirow[t]{2}{*}{ Average } \\
\hline & & & 1 & 2 & \\
\hline \multirow[t]{4}{*}{1} & \multirow{4}{*}{$\begin{array}{l}\text { Suitability of the questions with } \\
\text { basic competence }\end{array}$} & 1 & 3 & 3 & 3 \\
\hline & & 2 & 3 & 3 & 3 \\
\hline & & 3 & 3 & 3 & 3 \\
\hline & & 4 & 3 & 3 & 3 \\
\hline \multirow[t]{4}{*}{2} & \multirow[t]{4}{*}{ Accuracy of language use } & 1 & 3 & 3 & 3 \\
\hline & & 2 & 3 & 3 & 3 \\
\hline & & 3 & 3 & 3 & 3 \\
\hline & & 4 & 3 & 3 & 3 \\
\hline \multirow[t]{4}{*}{3} & \multirow{4}{*}{$\begin{array}{l}\text { The questions do not lead to } \\
\text { multiple interpretations. }\end{array}$} & 1 & 3 & 3 & 3 \\
\hline & & 2 & 3 & 3 & 3 \\
\hline & & 3 & 3 & 3 & 3 \\
\hline & & 4 & 3 & 3 & 3 \\
\hline \multirow[t]{4}{*}{4} & \multirow{4}{*}{$\begin{array}{l}\text { Clarity of what is known and what } \\
\text { is questioned }\end{array}$} & 1 & 3 & 3 & 3 \\
\hline & & 2 & 3 & 3 & 3 \\
\hline & & 3 & 3 & 3 & 3 \\
\hline & & 4 & 3 & 3 & 3 \\
\hline & Total & & 48 & 48 & 48 \\
\hline & Validity Percentage & & $80 \%$ & $80 \%$ & $80 \%$ \\
\hline
\end{tabular}


As depicted in table 5, both validator 1 and validator 2 stated that the posttest questions were valid with the percentage of $80 \%$. In other words, the whole posttest questions were valid.In addition to the validity test result, the researchers also considered suggestions and comments from the validators regarding the nonconformity of questions. The suggestions and comments are as follows: Choiru Umatin, M.Pd stated that in general, the media was good. Mustakim, S.Pd. stated that the level of questions must be noticed between one question to another question.

\section{Learning Process}

One of the stages in a research and development is analysis and experiment of creating a new product or developing the existing products. Developers design and test the effectiveness of the new or existing products. In this study, the media-assisted learning process was performed in class VII A and class VII B in three meetings. Of the three meetings, two of which were the learning process, while one meeting was intended for the posttest. As demonstrated in the learning process, the macromedia captivate-based media met some objectives of the media development. Firstly, the media enhanced learning independence. It was seen when the students were asked to learn independently, they comprehended the materials by following the guidelines provided in the media. The academic workers is inspired to use VLEs in numerous ways in which, together with as a platform to produce on-line access to the study material however additionally as a supply of further online module activities aimed toward enhancing student learning [14]. Therefore, when the teacher discussed the materials, a good interaction between the teacher and students occurred. Secondly, the media provided learning materials that facilitated the students to interact with the materials. This finding is consistent with [8] finding out that a macromedia captivate-based module was an interactive media. Interaction with the materials was evident when the students were able to perform a task independently either in a questioning session or doing exercises provided in the media. Students are not any longer confined to learning material from static sources like text books or stagnant websites transmission and therefore the web permit students to exper tise learning surroundings wealthy in data and experiences [15]. Thirdly, the media eased the teacher in explaining the materials. This was because the media assisted the students in constructing their understanding of a particular material. According to [16], Instructional media has many advantages in teaching English, particularly in teaching English to young learners. There are many advantages in utilizing educational mmedia in teaching English such as: attracting attention; developing interest; adjusting the educational atmosphere and promoting the acceptance of a thought. This is in line with [17] stating that one of the functions of instructional media is compensatory function, that is, it helps students who have low reading skill to organize information in a text and recall the information. The above mentioned benefits of the macromedia captivate-based instructional media clearly indicate that the media is able to make the learning process more effective. This finding supports [10] figuring out that the use of PBL-based macromedia captivate in the learning process was more effective than conventional learning.

A research and development focuses on designing a model, media, or process. It aims at creating a new product through several development stages. This study produced an instructional media concerning scarcity and human needs material. This instructional media was constructed by presenting materials in the beginning, and providing evaluations at the end. As previously mentioned, the target of this media was grade VII students. The instructional media in this study was developed by using macromedia captivate software. The final product of this media was packaged in SWF format as the main program, along with supporting files. To run the media, it just needs double click on the media files, and the media will instantly work. This macromedia captivate-based instructional media was designed for multiple functions. First, it is to support the classical learning process. Second, it is to make students learn independently.

The macromedia captivate-based instruct tional media has gone through validation and test stages. From the validation and test results, it was obtained several data that were further 
analyzed to investigate whether the media had a good quality, met validity, practicality, and effectiveness criteria, and helped the students understand scarcity and human needs material.
The numeric data were analyzed by using the stated formula. In addition, the descriptive data were also analyzed to revise the media. The following is the result of data analysis.

Table 6. Result of Validity Analysis of Instructional Media

\begin{tabular}{cclc}
\hline No & Validator & Percentage & Criteria \\
\hline 1 & Media Validator & $95.75 \%$ & Valid \\
\hline 2 & Material Validator & $93.65 \%$ & Valid \\
\hline
\end{tabular}

As table 6 shows, both material validator and media validator declared the media valid. This finding corresponds to [7], [8], [9], and [10] who concluded that macromedia captivate-based instructional media developed in diverse materials and approaches were valid and decent for educational use.

Practicality Analysis

1. The result of students' questionnaire

Referring to the questionnaire, the media was declared practical. The practicality average was $80.06 \%$.

2. Validator Evaluation

Based on the evaluation of the three validators, the media was declared valid with revision. The revision was done by referring to critiques and suggestions from the validators written in the validation sheet.

3. Tabulation of User Evaluation
Referring to the evaluation result, $93.3 \%$ of users (students) achieved the minimum score of $75 \%$. This percentage indicated that the media was a very good media.

4. Observation on Students' Activities In reference to the observation result during the try-out of the media, it was found that the media was applicable with minor revision.

\section{Effectiveness Analysis}

Based on the effectiveness analysis, the t-test result indicated the value of Sig. (2-tailed) $=0,000$. Since the value of Sig. (2-Tailed) was less than the significance value of $0.05(0.000<0.05), \mathrm{H}_{1}$ was accepted. It means that there was a significant difference between the experimental group and control group. Table 7 exemplifies the difference of average score between the experimental group and control group.

Table 7. Comparison Of Average Score Between Experimental Group And Control Group Average Score of Posttest

\begin{tabular}{cc}
\hline Control Group & Experimental Group \\
\hline $\mathbf{7 1 . 9 3}$ & 84.13 \\
\hline Difference of Average Score & 12.2 \\
\hline
\end{tabular}

The average score of the experimental group in the posttest was 84.13 , while the control group was only 71.93. The difference between the two groups was 12.2. Therefore, it can be concluded that there was a significant difference in learning outcomes between the experimental group and control group. This finding suggested that the macromedia captivate-based instructional media was an effective product. This was due to the improvement of the students' learning outcomes thanks to the application of the media. This finding supports Husna (2014 [10]) figuring out that the use of PBL-based macromedia captivate in the learning process was more effective than conventional learning. While, Eller (2015) [18] also claimed that captivate are often accustomed produce interactive materials, a lot of partaking lecture displays, or to deliver tests over a course/learning management system Instructional Design Using Adobe Captivate November 2015 - Volume 19, Number 3.

The media had some strengths and weaknesses. The strengths are as follows. 
a. As commented by the media experts, multimedia layout was attractive and communicative through suitable color combination, picture presentation, and understandable text.

b. The macromedia captivate-based instructional media consisted of texts, pictures, sounds, and music. $70 \%$ of those elements originated from the developers, and the remaining $30 \%$ originated from the Internet with modification. The modification was done by replacing English texts with Indonesian, and re-editing texts that were out of the material experts' concept. Hence, the texts were easily understood by students or users.

Apart from the strengths, the media had several weaknesses:

a. Production of this media took a lengthy time.

b. Time setting in this media was too complicated.

\section{CONCLUSIONS}

This study produced a macromedia captivate-based instructional media on Scarcity and Human Needs material of grade VII. This media was developed by adopting a research and development by Borg \& Gall (1983). The developments of this media used macromedia captivate software through validation and test stages. The data obtained from those stages were then analyzed to figure out the quality of the media.

Regarding the media validity, the media was evaluated by media experts and material experts. The evaluation resulted in the percentage of media validity of $95.75 \%$. It covered some aspects including layout, program, and learning. Referring to the percentage, the media experts declared the media valid. In addition to the media validity, the percentage of material validity was $93.65 \%$. The material validity engaged some aspects such as learning, material, and interaction. The percentage of material validity indicated that the media was valid, too.

In the case of practicality aspect, the data were obtained based on 4 indicators. First, the students' questionnaire resulted in the average score of $80.06 \%$. It suggested that the media was practical. Second, the validators' constructive evaluation suggested that the media was valid with revision. Third, tabulation of the users' evaluation showed the percentage of $93.3 \%$. In other words, $75 \%$ of the students achieved the minimum standard, that is, 75 . Fourth, the data of users' activities showed that $30 \%$ of the students asked questions during the learning process. This finding indicated that the media was practical.

Dealing with the effectiveness of this macromedia captivate-based instructional media, analysis of the posttest result using Independent Sample t-test revealed the value of Sig. (2-tailed) $=0,000$. Since the value of Sig. (2-Tailed) was less than the significance value of $0.05(0.000<0.05)$, $\mathrm{H} 1 \mathrm{was}$ accepted. It indicated that there was a difference between the experimental group and control group. This finding was made clearer by the average score of the posttest, revealing that the experimental group obtained the better result. The experimental group got 88.86 , while the control group only got 76.76. The difference was 12.1. Based on the comparison and analysis, it is clear that the experimental group outperformed the control group. In other words, a significant difference existed between the two groups. This finding revealed that the macromedia captivate-based instructional media on scarcity and human needs material was an effective product as it enhanced learning achievement on Social Studies.

Sciences, Maulana Malik Ibrahim StateIslamic University of Malang.

[4] Triharyati, D. A. \& Karyoto. (2016). Penggunaan Macromedia Captivate dengan Model PembelajaranGroup Investigation terhadap Pencapaian Hasil Belajar Siswa Pada Mata Pelajaran Gambar Konstruksi di SMK Negeri 5 Surabaya. Jurnal Kajian Pendidikan Teknik Bangunan, 2(2), pp. 191-199. 
[5] Larasati, I. and Karyoto. (2014). Penggunaan Macromedia Captivate dengan Model Pembela jaran Make a Match terhadap Pencapaian Hasil Belajar Siswa pada Kompetensi Dasar Memahami berbagai Tipe Pondasi. Jurnal Kajian Pendidikan Teknik Bangunan, 3(1), pp. 50-58.

[6] Herawati. (2015). Pengembangan Modul E- Learning Fisika Berbasis Captivate. Jurnal Pendidikan Terbuka dan Jarak Jauh, 16(2), pp. 68-75.

[7] Suryani, D. Y. (2013). Pengembangan media pembelajaran matematika berbasis kontekstual dengan pemanfaatanMacromedia Captivate pokok bahasan kubus dan balok. Thesis. Faculty of Mathematics Education and Natural Science of IKIP PGRI Semarang.

[8] Yuliana, A. M. (2011). Pengembangan Modul Interaktif Materi Fluida menggunakan Macromedia Captivateuntuk siswa kelas XI SMA 9 Bandar Lampung. Thesis. Faculty of Teacher Training and Education.Universitas Lampung.

[9] Anggreini, D. T. (2016). Penggunaan Macromedia Captivate Dengan Model Pembelajaran Group Investigation Terhadap Pencapaian Hasil Pada Mata Pelajaran Gambar Konstruksi Di SMK Negeri 5 Surabaya. Jurnal Kajian Pendidikan Teknik Bangunan, 2(2).

[10] Husna, A. B. (2014). Pengembangan CD Interaktif SMP Berbantuan Macromedia Captivate melalui Pendekatan PBL (Problem Based Learning) pada Materi Bangun Datar Segitiga. Proceeding of Mathematics and Sciences Forum,
Mathematics Education of Universitas PGRI Semarang.

[11] Sugiyono. (2017). Metode Penelitian: pendekatan kuantitatif, kualitatif, dan RED. Bandung: Alfabeta.

[12] Borg, W.R. and Gall, M.D. Gall. (1983). Educational Research: An Introduction, Fifth Edition. New York: Longman

[13] Sukmadinata, N. S. (2013). Metode Penelitian Pendidikan. Bandung: PT Remaja Rosdakarya.

[14] Chowdhry, Sieler, and Alwis. (2014). A Study of the Impact of TechnologyEnhanced Learning of Student Academic Performance Sandeep. Journal of Perspectives in Applied Academic Practice, 2(3), pp. 3-15.

[15] Tucker, Jan and Courts, Bari (2010). Utilizing The Internet To Facilitate Classroom Learning. Journal of College Teaching \& Learning (TLC). 7(7). Undangundang Dasar Negara Republik Indonesia Tahun 1945 (UUD'45). (Surabaya: Anugerah).

[16] Sukmahidayanti, Tanti. (2015). The Utilization of Instructional Media In Teaching English To Young Learners (A Case Study of An Elementary School Teacher In Bandung). Journal of English and Education, 3(2), pp. 90-100.

[17] Arsyad, R. (2011). Kreatif Mengembangkan Media Pembelajaran. Jakarta: Tim GP Press.

[18] Eller, Ryan. (2015). Instructional Design Using Adobe Captivate. The Electronic Journal for English as a Second Language, 19 (3), pp. 1-7. 